\title{
Pulse-width modulation in the autonomous voltage inverter in identifying parameters of the three-phase asynchronous motor
}

\author{
Valery Makarov ${ }^{1}$, Veronika Zagirova ${ }^{1, *}$, and Georgii Vagapov ${ }^{2}$ \\ ${ }^{1}$ Kazan National Research Technological University, Department of Electric Operations and Engineering Kazan, Russia \\ ${ }^{2}$ Engineering center of Kazan State Power Engineering University, Research-and-development division, Kazan, Russia
}

\begin{abstract}
This paper deals with control algorithm of a two-level autonomous voltage inverter with pulsewidth modulation in forming test phase voltages for identification of parameters of a three-phase asynchronous motor. Necessary conversion is carried out, the laws of change of phase voltages of an autonomous inverter are obtained. The feasibility of using third order active Butterworth filters for determining first harmonics of phase voltages is shown. By means of computer simulation and experimental research, it is revealed that the required shapes of phase voltages can be implemented in a twolevel autonomous voltage inverter with pulse-width modulation, and the presence of Butterworth filters does not introduce significant distortion and allows to obtain necessary phase voltage shapes in the generalized electric machine.
\end{abstract}

\section{Introduction}

For implementation of laws of frequency regulation of speed in the asynchronous motor (AC), it is necessary to be armed with data on current parameter values of phase-substitution and load circuit. This information allows to implement more accurate algorithms of frequency regulation of speed. And this provides energy efficiency and resource saving.

There are various methods of parameters identification [1 - 5]. In [6-13] efficiency of using continuous gradient method of minimum search of positive definite function for parametric identification of a three-phase asynchronous motor (AC) and its load is shown. In $[7,8,11]$ identification is carried out by the five parametres of phase-substitution circuit of AC which include active winding resistance of stator $R_{1}$, winding inductance of stator $L_{1}$, mutual inductance $M_{m}$ , active winding resistance of rotor $R_{2}$, winding inductance of rotor $L_{2}$. Load parameters are static moment $M_{s}$ and joint inertia of moving parts $J_{\Sigma}$. The total number of identified parameters is seven.

In $[7-10]$, a computer simulation of the identification processes of the parameters of a threephase asynchronous motor (AC) and its load was carried out. The basis of the asynchronous motor model was the mathematical description of the generalized electrical machine (GEM). When simulating, the phase voltages of the stator winding were set in the form of test signals. The specifics of the operation of the frequency converter and the influence of pulse-width modulation (PWM) were not taken into account. PWM algorithms are given in [14]. In this case, when identifying the parameters of the asynchronous motor, the shape and frequency of the output voltages of the frequency converter (FC) will depend on the laws of change in the test signals

The purpose of this article is to analyze the feasibility of technical implementation of the output voltages of the frequency converter with test signals and filtering the high-frequency components of these voltages.

\section{Methods}

In most cases, algorithms of frequency regulation of speed are based on mathematical description and parameters of the generalized electric machine $[14,15$, 16]. Thus, for identification of parameters we use the equation system of the generalized electric machine (GEM) on the basis of three-phase asynchronous motor (AC) $[7,8,11,17,18]$.

$$
\left\{\begin{array}{l}
u_{1 d}=R_{1} i_{1 d}+L_{1} \frac{d i_{1 d}}{d t}+M_{m} \frac{d i_{2 d}}{d t}-\omega_{1}\left(L_{1} i_{1 q}+M_{m} i_{2 q}\right) \\
u_{1 q}=R_{1} i_{1 q}+L_{1} \frac{d i_{1 q}}{d t}+M_{m} \frac{d i_{2 q}}{d t}+\omega_{1}\left(L_{1} i_{1 d}+M_{m} i_{2 d}\right) \\
0=R_{2} i_{2 d}+L_{2} \frac{d i_{2 d}}{d t}+M_{m} \frac{d i_{1 d}}{d t}-\omega_{2}\left(L_{2} i_{2 q}+M_{m} i_{1 q}\right) \\
0=R_{2} i_{2 q}+L_{2} \frac{d i_{2 q}}{d t}+M_{m} \frac{d i_{1 q}}{d t}+\omega_{2}\left(L_{2} i_{2 d}+M_{m} i_{1 d}\right) \\
J_{\Sigma} \frac{d \omega}{d t}=p_{\text {пा }}\left(M_{\mathrm{e}}-M_{\mathrm{S}}\right) \\
M_{\text {э }}=p_{\mathrm{p}} M_{m}\left(i_{2 d} i_{1 q}-i_{2 q} i_{1 d}\right)
\end{array}\right.
$$

where $u_{1 d}, u_{1 q}$ - are stator winding phase voltages; $i_{1 d}$, $i_{1 q}, i_{2 d}, i_{2 q}$ - are currents of stator and rotor winging;

\footnotetext{
* Corresponding author: regist1234@mail.ru
} 
$\omega_{1}$ - is angular velocity of rotating coordinate system $d$, $q ; \omega_{2}-$ is angular slip velocity $\left(\omega_{2}=\omega_{1}-\omega\right) ; \omega$ - is angular rotation velocity of rotor, $\mathrm{rad} / \mathrm{s} ; p_{\mathrm{p}}$ - is number of pole pairs; $M_{e}$ - is electromagnetic torque; $M_{s}$ - is static moment.

Transition from parameters and values of a threephase asynchronous motor (AC) to the ones of the generalized electric machine (GEM) and vica versa is discussed in $[17,18]$. Conversion of phase voltages of a GEM stator in voltages of a stator of the three-phase asynchronous motor (AC) takes the form [17, 18]

$$
\begin{gathered}
u_{1 A}=u_{1 d} \cos \alpha_{1}-u_{1 q} \sin \alpha_{1} \\
u_{1 B}=u_{1 d} \cos \left(\alpha_{1}-\frac{2 \pi}{3}\right)-u_{1 q} \sin \left(\alpha_{1}-\frac{2 \pi}{3}\right) \\
u_{1 C}=u_{1 d} \cos \left(\alpha_{1}+\frac{2 \pi}{3}\right)-u_{1 q} \sin \left(\alpha_{1}+\frac{2 \pi}{3}\right)
\end{gathered}
$$

where $\alpha_{1}$ is shaft rotation angle of axis $d$ of coordinate system $d, q$ about axis $A$ of stator.

Angle $\alpha_{1}$

$$
\alpha_{1}=\int_{0}^{t} \omega_{1}(t) d t
$$

Computer simulation of parameters identification processes of the asynchronous electric drive with motor AIR80A6U2 was carried out in [8]. Voltages $u_{1 d}(t)$, $u_{1 q}(t)$ and angle velocity $\omega_{1}(t)$ were changing in accordance with timing diagrams in Figure 1 and were characterized by the parameters presented in Table 1 .
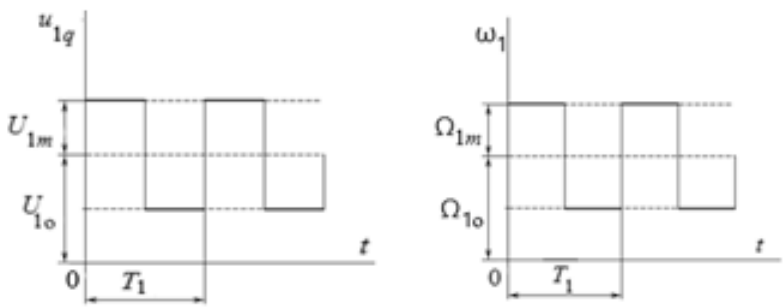

Fig. 1. Timing diagrams of functions $u_{1 q}(t)$ and $\omega_{1}(t)$.
Table 1. Function parameters $u_{1 q}(t)$ and $\omega_{1}(t)$.

\begin{tabular}{|l|c|c|c|}
\hline \multirow{2}{*}{ Parameter name } & \multicolumn{2}{c|}{ Function } \\
\cline { 3 - 4 } \multirow{2}{*}{$\begin{array}{l}\text { Constant } \\
\text { component }\end{array}$} & Designation & $u_{1 q}(t)$ & $\omega_{1}(t)$ \\
\cline { 2 - 4 } & $\begin{array}{c}\text { Value, the unit of } \\
\text { measurement }\end{array}$ & $\Omega_{1 \mathrm{o}}$ \\
\hline $\begin{array}{l}\text { Amplitude } \\
\text { of variable } \\
\text { component }\end{array}$ & $\begin{array}{c}\text { Vesignation } \\
\text { measurement }\end{array}$ & $\begin{array}{c}300 \\
\mathrm{rad} / \mathrm{s}\end{array}$ \\
\cline { 2 - 4 } $\begin{array}{l}\text { Frequency } \\
\text { of variable } \\
\text { component }\end{array}$ & \begin{tabular}{c} 
Designation \\
\cline { 2 - 4 }
\end{tabular} & $\begin{array}{c}\text { Value, the unit of } \\
\text { measurement }\end{array}$ & \multicolumn{2}{|c|}{$\Omega_{1 \mathrm{~m}}$} \\
\hline
\end{tabular}

From Figure 1 it is clear that the functions $u_{1 q}(t)$ and $\omega_{1}(t)$ are periodical. Period of their variations is taken as $T_{1}$. Let us agree to call $u_{1 d}(t), u_{1 q}(t)$ and $\omega_{1}(t)$ test signals. Computer simulation in [8] confirmed efficiency, working capacity and high accuracy of the suggested identification method and of the algorithm that was worked out on its basis. For analysing feasibility of phase voltages of stator winding $u_{1 A}(t), u_{1 B}(t), u_{1 C}(t)$ under test signals, computer simulation was conducted [19].

\section{Results and Discussion}

Results of computer simulation in the form of timing diagrams of angular velocity $\omega_{1}(t)$, rotation angle $\alpha_{1}$ and voltages $u_{1 q}(t), u_{1 A}(t)$ are given in Figure 2 . Analysis of the curve $u_{1 A}(t)$ shows that phase voltages are amplitude-frequency modulated oscillations. Amplitude changes according to variations of voltage amplitude $u_{1 q}(t)$, and frequency changes according to angular velocity variations $\omega_{1}(t)$. 

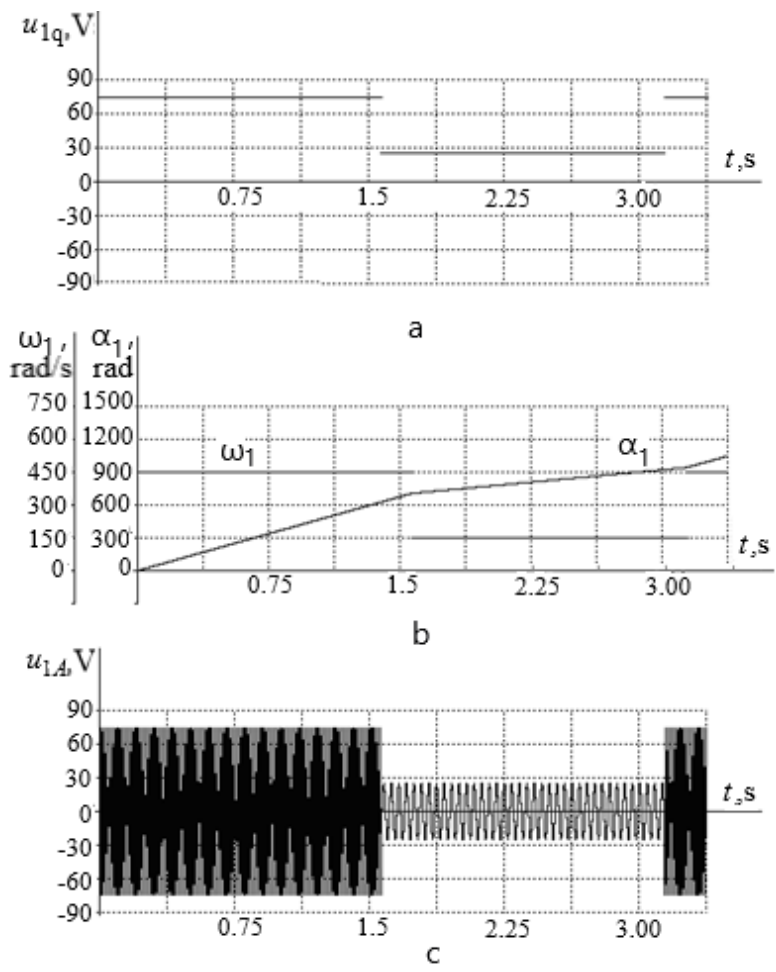

Fig. 2. Timing diagrams of voltage $u_{1 q}$ (a), angular velocity $\omega_{1}$ and rotation angle $\alpha_{1}$ (b), amplitude-frequency modulated voltage $u_{1 A}$ (c).

In a larger timescale, for the first and the second
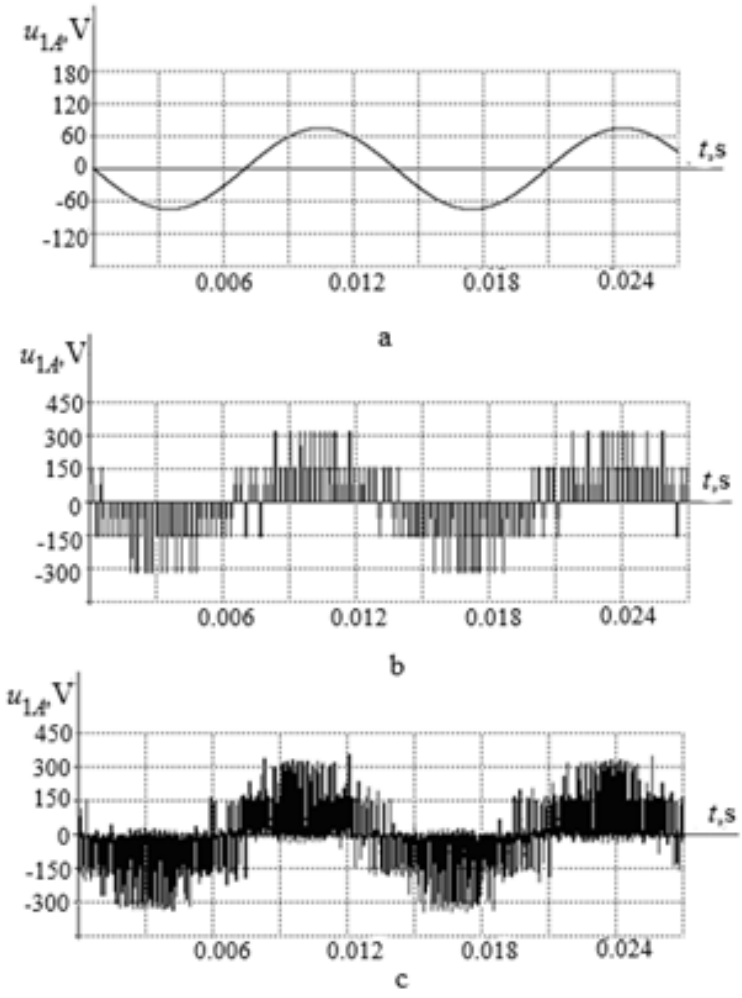

halves of period $T_{1}$, the curve $u_{1 A}(t)$ is shown in Figure 3 a, d. During the first half of period $T_{1}$, voltage $u_{1 A}(t)$ varies with time according to harmonic law with amplitude $75 \mathrm{~V}$ and frequency $71.6 \mathrm{~Hz}$, and during the second half of period $T_{1}$ with amplitude $25 \mathrm{~V}$ and frequency $23.8 \mathrm{~Hz}$. In a similar way, with angle shift $-2 \pi / 3$ and $2 \pi / 3$, voltages $u_{1 B}(t), u_{1 C}(t)$ will change correspondingly.

To implement phase voltages $u_{1 A}(t), u_{1 B}(t), u_{1 C}(t)$ , it is necessary to change simultaneously their rootmean-square values and frequency.

In most modern asynchronous electric drives, indirect frequency converters (FC) are used. They comprise uncontrolled rectifier (UR) and two-level autonomous voltage inverter (AVI). To operate transistors of the autonomous voltage inverter, pulse-width modulation (PWM) is applied. Phase voltages of AVI with PWM represent pulse string, amplitude and duration of which change directly with control voltages.

Simulation of AVI with PWM was conducted providing three-phase mains supply of indirect frequency converter (FC) has voltage $390 \mathrm{~V}$, frequency $50 \mathrm{~Hz}$. In this case rectified voltage in DC link [21] takes the form of

$$
U_{d}=1.35 \cdot U_{1 \mathrm{~L}}
$$

where $U_{1 \mathrm{~L}}$ is root-mean-square value of line-to-line supply voltage.
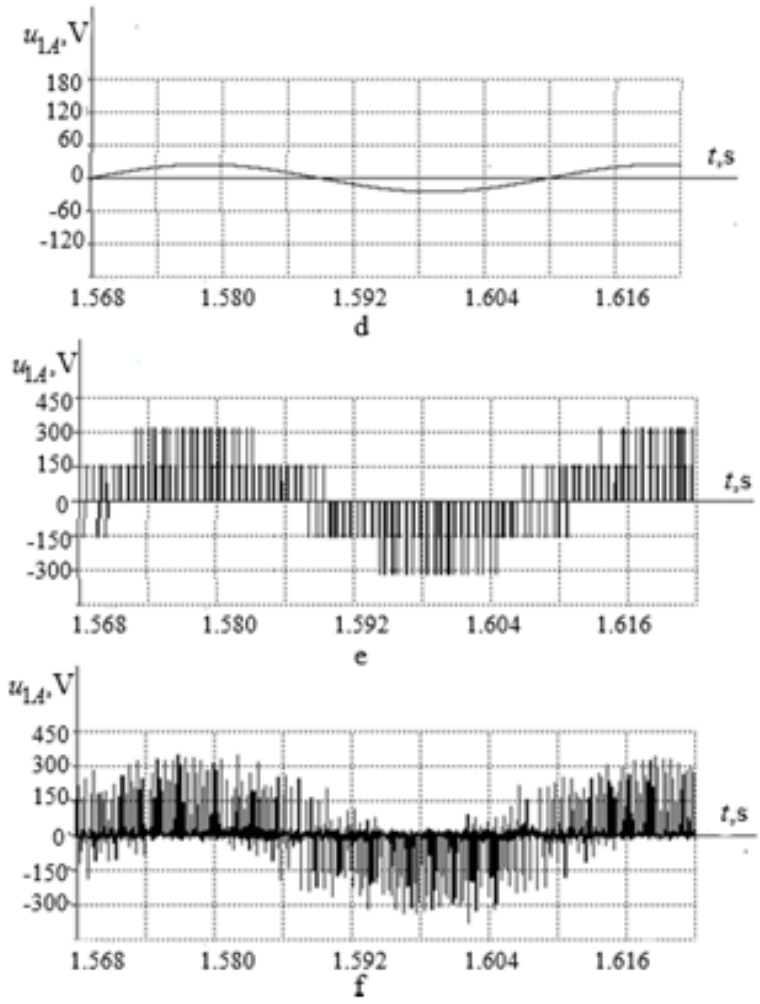

Fig. 3. Timing diagrams of voltage $u_{1 A}$ for the first (a, b, c) and the second ( $\mathrm{d}, \mathrm{e}, \mathrm{f}$ ) half of the period $T_{1}$ a, $\mathrm{d}$ - amplitudefrequency modulated voltage; b, e - calculated curve with PWM; c, f - experimental curve with PWM). 

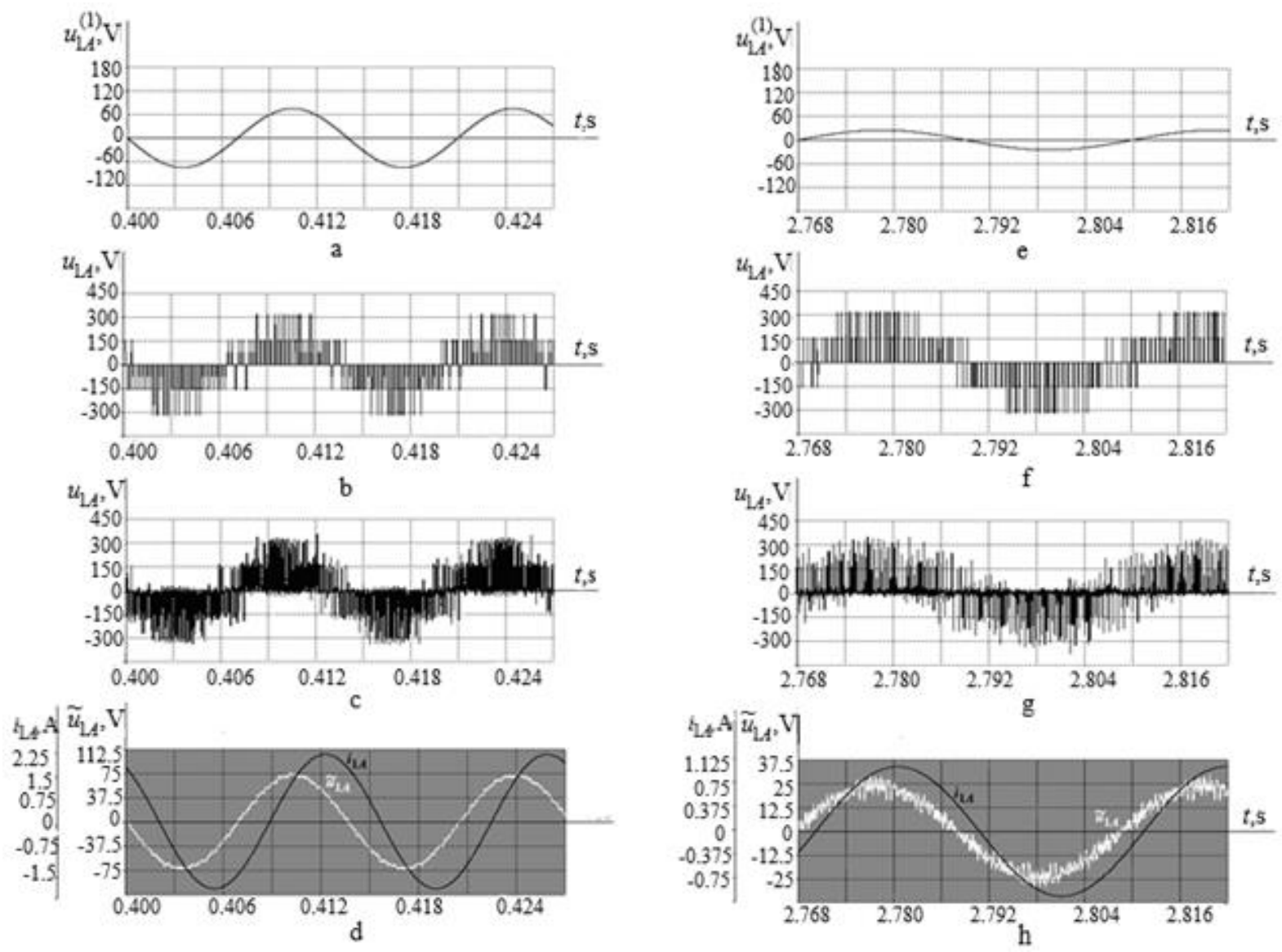

Fig. 4. Timing diagrams for the first (a, b, c, d) and second (e, f, g, h) halves of the period $T_{1}$ (a, e - first (main) harmonic $u_{1 A}^{(1)}$; $\mathrm{b}, \mathrm{f}$ - calculated curve $u_{1 A}$ with PWM; c, g-experimental curve $u_{1 A}$ with PWM; $\mathrm{d}, \mathrm{h}$ - experimental curves voltage $\tilde{u}_{1 A}$ in the outputof low-pass filter (LPF) and current $i_{1 A}$ )

Not taking account of voltage drop in diodes of uncontrolled rectifier, in accordance with (6), we get

$$
U_{d}=1.35 \cdot 380=513 \mathrm{~V}
$$

In simulation, voltage drop in diodes of uncontrolled rectifier and in on-transisters of AVI was taken into consideration. Control voltages of AVI were taken as proportional to voltages $u_{1 A}(t), u_{1 B}(t), u_{1 C}(t)$.

Results of computer simulation are presented in Figure $3 \mathrm{~b}, 3 \mathrm{e}$ in the form of timing diagrams of phase voltages $u_{1 A}(t)$ for the first and the second halves of period $T_{1}$. Analysis of the diagrams shows that phase voltages of AVI with PWM are periodical time functions. They represent pulse string with amplitude $165 \mathrm{~V}$ and $330 \mathrm{~V}$ with reposes at zero-low. Duration and pulse height change according to variations of amplitude-frequency modulated control voltages. Pulse heights are equal to $\frac{1}{3} U_{d}$ and $\frac{2}{3} U_{d}$. This corresponds with description of PWM algorithm in [14, 20, 22]. Results of computer simulation are in agreement with theory and applications of power-operated converter equipment and variable frequency electric drive.
Experimental research was conducted in the scientific laboratory at Kazan National Research Technological University using indirect frequency converter (FC). The objective of the experiment is qualitative analysis of phase voltage curves of AVI with PWM along with test signals. Powerpart of with PWM was carried out with intelligent power modul (IPM) PS22A73 by Mitsubishi Electric. Actuating system was performed with microcontroller $d s P I C 30 F 3010$.

Frequency of pulse-width modulation was taken equal to $16 \mathrm{kHz}$. Experiment results are presented in Figure $3 \mathrm{c}$ and Figure $3 \mathrm{f}$ in the form of timing diagrams of phase voltages $u_{1 A}(t)$ for the first and second halves of period $T_{1}$. Comparative qualitative analysis of timing diagrams highlights good agreement of calculated (Figure 3 b, 3 e) and experimental curves (Figure 3 e, 3 f).

In pulse-width modulation (PWM), output voltages of frequency converter (FC) represent pulse string. Duration of the pulses changes proportionally to control voltages. Impact of PWM leads to occurrence of highfrequency components in phase voltage spectrum of FC.

Thus, for identification of parameters of three-phase asynchronous motor it is necessary to perform filtration 
of phase voltages of $\mathrm{FC}$ with their further conversion $[22,23]$.

The aim of computer simulation is to analyse the curves of output voltages of indirect frequency converter (FC) with identification of parameters of three-phase asynchronous motor. By means of computer simulation, for the first and second halves of period $T_{1}$, amplitude-frequency modulated voltage curves $u_{1 A}^{(1)}(t)$ and calculated curves $u_{1 A}(t)$ with PWM are obtained. The curves are presented in Figure $4 \mathrm{a}, \mathrm{b}$ and Figure 4 e, $\mathrm{f}$, correspondingly.

Evidently, that in phase voltage spectrum of FC there are high-frequency components. For high-frequency components cutoff, low-pass filters (LPF) are used. Taking into considerations [24 - 28], analysis of circuitry and LPF characteristics was conducted. It was found that for filtration of phase voltages of (FC), it is reasonable to use third order Butterworth filters. Transfer function of such filter is given [28]

$$
W(p)=\frac{k_{\mathrm{f}}}{T_{\mathrm{f}}^{3} p^{3}+2 T_{\mathrm{f}}^{2} p^{2}+2 T_{\mathrm{f}} p+1}
$$

where $k_{f}, T_{f}$ are transmission factor and filter time constant.

Filter time constant differs according to cutoff frequency $f_{\mathrm{c}}$

$$
T_{\mathrm{f}}=\frac{1}{2 \pi f_{\mathrm{c}}}
$$

Cutoff frequency of LPF was taken equal to $5 \mathrm{kHz}$ and was chosen considering the following :

1) minimum $\omega_{1 \min }$ and maximum $\omega_{1 \max }$ circular frequencies of the desired signal in Figure 5 are evaluated on account of values $\Omega_{10}$ and $\Omega_{1 m}$ of function $\omega_{1}(t)$ from Table 1 ;

2) circular frequency of reference voltage $\omega_{\text {ref }}$ is determined by PWM frequency which was set equal to $16 \mathrm{kHz}$;

3) effect of LPF on voltage conversion should be minimal.

In Figure 5 frequency response of third order Butterworth filter with cutoff frequency $5 \mathrm{kHz}$ is shown. The response is determined on account of transfer function proved that $k_{f}$ equals 1 .

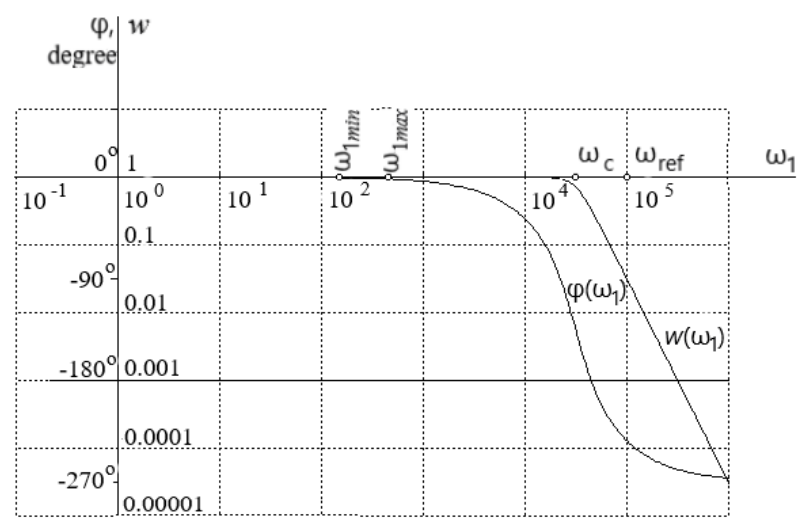

Fig. 5. Frequency response of third order Butterworth filter.

Analysis of amplitude-frequency characteristics (AFC) in Figure 5 shows that with circular frequency $\omega_{1}$ lower than circular cutoff frequency $\omega_{c}$, it is at the level of 1 , while with circular frequency $\omega_{1}$ higher than $\omega_{\mathrm{c}}$, it has the slope of $60 \mathrm{~dB} / \mathrm{dec}$. This is decisive advantage when choosing LPF type. Evidently, that amplitude distortion with circular frequencies of the desired signal $\omega_{1 \min }$ and $\omega_{1 \max }$ will be minimal. Analysis of circuit phase responce in Figure 5 shows, that in the field of circular frequency of the desired signal $\omega_{1 \min }$ and $\omega_{1 \max }$, the filter will not cause significant lag.

Experimental setup scheme is given in Figure 6. The sensor unit in Figure 6 comprises voltage sensing devices and current sensing devices, Hall effect devices, rotation velocity sensors and angular accelerometers. Hall devices are installed in stator bore in orthogonal axes. Filter bank comprises six third order Butterworth filters. Frequency converter (FC) is not shown in Figure 6.

The aim of the experiment is analysis of output voltage curves of third order Butterworth filters and analysis of results of conversion of output voltage of the filters into voltages of coordinate system $d, q$.

Results of the experiment are presented in Figure $4 \mathrm{c}$, $\mathrm{d}, \mathrm{g}, \mathrm{h}$ in the form of timing diagrams of phase voltages of frequency converter (FC) and output voltages of LPF for the first and second halves of period $T_{1}$.

In Figure $7 \mathrm{~b}$ there are timing diagrams of voltages $\tilde{u}_{1 d}(t), \quad \tilde{u}_{1 q}(t)$ formed on account of LPF output voltages. Experimental timing diagrams of output voltages of LPF in Figure $4 \mathrm{~d}, \mathrm{~h}$ are combined with timing diagrams of phase currents $i_{1 A}(t)$. Phase current curves of the asynchronous motor represent fairly smooth harmonic functions and, thus, do not need filtration. Experimental curves are performed using packet Power Craph 3.3. Conversion of output voltages of LPF into phase voltages of stator winding of GEM takes the form of $[17,18]$

$$
\tilde{u}_{1 d}=\frac{2}{3}\left[\tilde{u}_{1 A} \cos \alpha_{1}+\tilde{u}_{1 B} \cos \left(\alpha_{1}-\frac{2 \pi}{3}\right)+\tilde{u}_{1 C} \cos \left(\alpha_{1}+\frac{2 \pi}{3}\right)\right](9)
$$




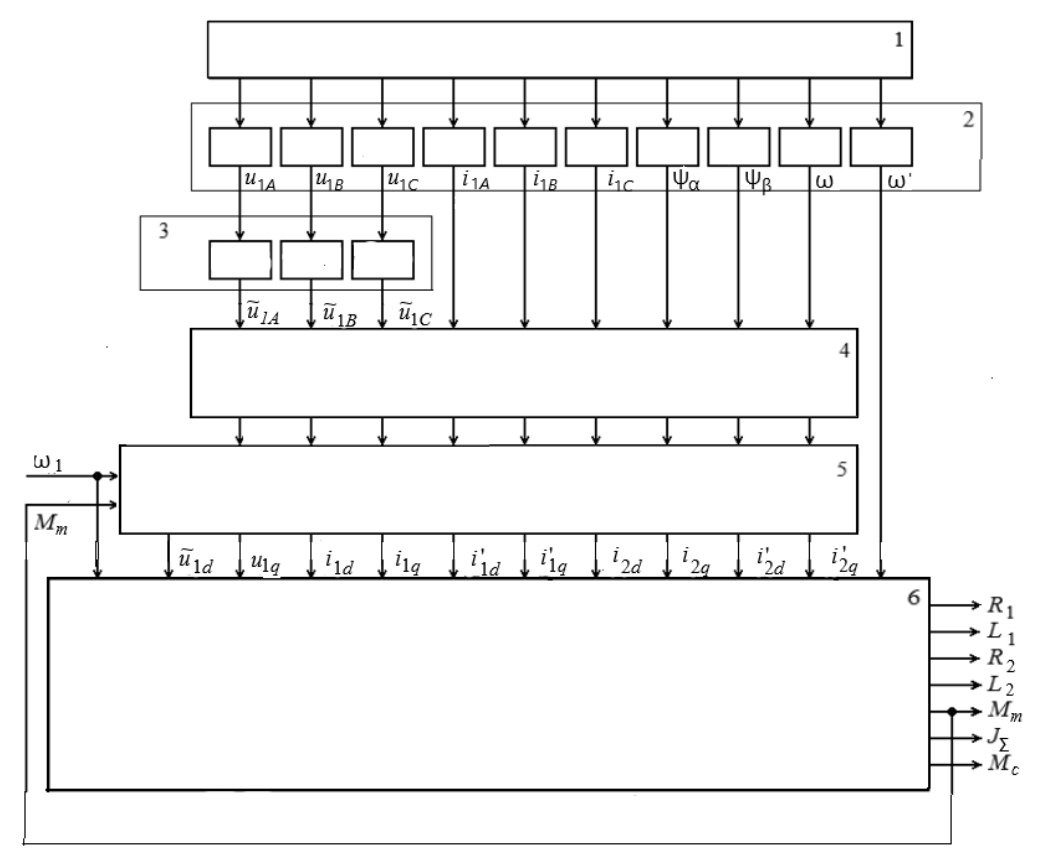

Fig. 6. Experimental setup diagram (Block 1 - Induction motor; block 2 - Sensor unit; block 3 - Filter unit; block 4 - Analog-todigital converter; block 5 - Coordinate converter; block 6 - Parameter identification device).

$$
\tilde{u}_{1 q}=-\frac{2}{3}\left[\tilde{u}_{1 A} \sin \alpha_{1}+\tilde{u}_{1 B} \sin \left(\alpha_{1}-\frac{2 \pi}{3}\right)+\tilde{u}_{1 C} \sin \left(\alpha_{1}+\frac{2 \pi}{3}\right)\right]^{(10)}
$$

Curves of output voltages of LPF in Figure $4 \mathrm{~d}, \mathrm{~h}$ are not ideally smooth harmonic functions. In spectrum of LPF output voltages there is high-frequency ripple. Most significantly they are revealed in the second half of period $T_{1}$ (Figure $4 \mathrm{~h}$ ). This is explained by relatively small amplitude value of the first harmonic of phase voltage $u_{1 A}^{(1)}(t)$ which is $25 \mathrm{~V}$. On account of $(5),(9)$, (10), curves $u_{1 d}(t), u_{1 q}(t)$ are formed, they are given in Figure $7 \mathrm{~b}$. Becaue of the PWM effect, the curves contain high-frequency ripple with amplitude no more than $3 \mathrm{~V}$.
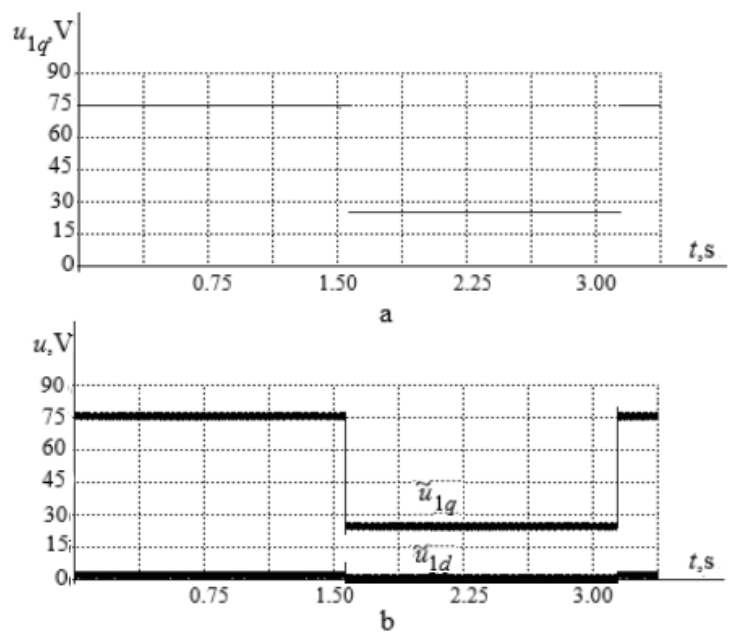

Fig. 7. Calculated (a) and experimental (b) curves of phase voltages of GEM stator.
For qualitative evaluation of effect of third order Butterworth filters, analysis of frequency response was conducted, it is presented in Figure 5. Results are shown in Table 2.

Table 2. Results of analysis of the filter frequency response.

\begin{tabular}{|c|c|c|c|}
\hline \multirow{2}{*}{$\begin{array}{c}\text { Frequency response, } \\
\text { units of measurement }\end{array}$} & \multicolumn{3}{|c|}{ Circular frequencies } \\
\cline { 2 - 4 } & $\omega_{1 \text { min }}$ & $\omega_{1 \text { max }}$ & $\omega_{\text {ref }}$ \\
\hline$w\left(\omega_{1}\right)$ & 1 & 1 & 0.03 \\
\hline$A\left(\omega_{1}\right), \mathrm{dB}$ & 0 & 0 & -30.3 \\
\hline$\phi\left(\omega_{1}\right)$, degree & -1.59 & -2.13 & -233 \\
\hline
\end{tabular}

According to data of Table 2, with circular frequencies of the desired signal $\omega_{1 \text { min }}$ and $\omega_{1 \text { max }}$, amplitude variations of LPF output voltage are not registered. Phase lag is equal to $1.59^{\circ}$ and $2.13^{\circ}$, correspondingly. Circular frequency $\omega_{\text {ref }}$ in this case is considered as interfering frequency. At this frequency, amplitude attenuation of LPF output voltage and phase lag by $233^{\circ}$ are observed.

\section{Conclusion}

The conducted analysis allowed to find out that third order Butterworth filters do not significantly influence the desired signal and provide efficient cutoff of highfrequency interference. Experimental research allowed to establish, that the use of indirect frequency converter (FC) with PWM and Butterworth filters makes it possible to a high precision to perform transition in phase voltages of GEM stator winding. When this happens, identification processes stability is reserved, 
and in identification of the aforementioned parameters of a three-phase asynchronous motor and its load, with initial deflection from true values by $50 \%$, relative error is not higher than $7 \%[20]$.

\section{References}

1.1 1. O. Cetin, A. Dalcali, F. Temurtas, Engineering Science and Technology, an International Journal, 23, 1126 (2020)

1.2 2. J. Guedes, M. Castoldi, A. Goedtel, C. Agulhari, D. Sanches, Electric Power Systems Research, 154, 204 (2018)

1.3 3. X. Qi, Engineering Applications of Artificial Intelligence, 72, 67 (2018)

1.4 4. Y. Kouhi, J. Kertzscher, IFACPapersOnLine, 50, 1577 (2017)

1.5 5. M. Jirdehi, A, Rezaei, Alexandria Engineering Journal, 55, 357 (2016)

6. A.J. Afanasiev, Momentnyj jelektroprivod (The torque electric drive) (Kazan, Publishing house of Kazan State Technical University, 250, 1997) (in Russian)

7. V.G. Makarov, Identifikacija parametrov trehfaznogo asinhronnogo dvigatelja (Identification of parameters of the three-phase the asynchronous motor), Problemy Jenergetiki, 3-4, 88-101 (2010) (in Russian)

8. A.J. Afanasiev, V.G. Makarov, J.A. Yakovlev, V.N. Khannanova, Ustrojstvo identifikacii parametrov trehfaznogo asinhronnogo dvigatelja (Parameter identification device for three-phase asynchronous motor), Izvestija Vysshih Uchebnyh Zavedenii, Problemy Jenergetiki, 5-6, 107-119 (2015) (in Russian)

9. V.G. Makarov, Identifikacija parametrov i tokov rotora trehfaznogo asinhronnogo dvigatelja (Identification of parameters and currents of the rotor three-phase the asynchronous motor), Problemy Jenergetiki, 7-8, 101-116 (2010) (in Russian)

10. A.J. Afanasiev, V.G. Makarov, J.A. Yakovlev, V.N. Khannanova, Ustrojstvo identifikacii parametrov i tokov rotora trehfaznogo asinhronnogo dvigatelja (Device for identifying parameters and currents of a rotor of a threephase asynchronous motor), Izvestija Vysshih Uchebnyh Zavedenii. Problemy Jenergetiki, 3-4, 101-113 (2015) (in Russian)

11. V.G. Makarov, A.J. Afanasiev, J.A. Yakovlev, The patent 2392731, Russian Federation, Ustrojstvo ocenivanija parametrov jelektrodvigatelja (The device of estimation of parametres of electric motor), 2009118685/09, declarant and patentee Kazan State Technological University, it is declared 18.05.2009, it is published 20.06.2010, bul. 17, 21 (2010) (in Russian)
12. V.G. Makarov, A.J. Afanasiev, J.A. Yakovlev, The patent 2426219, Russian Federation, Ustrojstvo ocenivanija parametrov asinhronnogo jelektrodvigatelja (The device of estimation of parametres of electric motor), 2010112365/07, declarant and patentee Kazan State Technological University, it is declared 30.03 .2010 , it is published 10.08.2011, bul. 22, 24 (2011) (in Russian)

13. V.G. Makarov, Aktual'nye problemy asinhronnogo jelektroprivoda i metody ih reshenija (Actual problems of an asynchronous electric drive and methods for their solution), Vestnik Kazanskogo Tehnologicheskogo Universiteta, 14 (6), 79-93 (2011) (in Russian)

14. G.G. Sokolovskij, Jelektroprivody peremennogo toka $s$ chastotnym regulirovaniem (Variable frequency AC drives) (Moscow, Akademija, 272, 2006) (in Russian)

15. V.M. Terehov, O.I. Osipov, Sistemy upravlenija jelektroprivodov (Electric drive control systems) (Moscow, Akademija, 304, 2006) (in Russian)

16. D. White, G. Woodson, Jelektromehanicheskoe preobrazovanie jenergii (Electromechanical energy conversion) (Moscow, Energiya, 527, 1964) (in Russian)

17. V.G. Makarov, Primenenie teorii obobshhennoj jelektricheskoj mashiny $\mathrm{k}$ trehfaznomu asinhronnomu dvigatelju (Application of the theory of the generalized electrical machine to the three-phase asynchronous motor), Problemy Jenergetiki, 11-12, 84-97 (2010) (in Russian)

18. V.G. Makarov, Gipoteticheskaja fizicheskaja model' obobshhennoj jelektricheskoj mashiny na osnove trehfaznogo asinhronnogo dvigatelja (Hypothetical physical model of the generalized electrical machine on the basis of the three-phase asynchronous motor), Problemy Jenergetiki, 1-2, 94-108 (2010) (in Russian)

19. V.G. Makarov, V.N. Khannanova, J.A. Yakovlev, Shirotno-impul'snaja moduljacija $\mathrm{v}$ avtonomnom invertore naprjazhenija pri identifikacii parametrov trehfaznogo asinhronnogo dvigatelja (Pulse-width modulation in an autonomous voltage inverter for identifying parameters of a three-phase asynchronous motor), I Povolzhskaja Nauchno-Prakticheskaja

Konferencija «Priborostroenie i Avtomatizirovannyj Jelektroprivod v Toplivno-jenergeticheskom Komplekse i Zhilishhno-kommunal'nom Hozjajstve», Kazan, 532-535 (2015) (in Russian)

20. B. Bose, Power Electronics and Motor Drives (2006)

21. V.A. Eliseev, A.V. Shinjanskij, Spravochnik po avtomatizirovannomu jelektroprivodu (Handbook of automated electric drive, Moscow, Jenergoatomizdat, 456, 1988) (in Russian)

22. V.G. Makarov, V.N. Khannanova, J.A. Yakovlev, Komp'juternoe modelirovanie algoritma 
upravlenija avtonomnym invertorom naprjazhenija pri identifikacii parametrov i tokov korotkozamknutogo rotora trehfaznogo asinhronnogo dvigatelja (Computer simulation of an autonomous voltage inverter control algorithm for identifying parameters and currents of a squirrel-cage rotor of a three-phase asynchronous motor), Vestnik Kazanskogo Tehnologicheskogo Universiteta, 18 (22), 149-153 (2015) (in Russian)

23. A.J. Afanasiev, V.G. Makarov, V.N. Khannanova, J.A. Yakovlev, Fil'tracija faznyh naprjazhenij preobrazovatelja chastoty pri identifikacii parametrov trehfaznogo asinhronnogo dvigatelja (Filtration of phase voltages of the frequency converter when identifying parameters of a three-phase asynchronous motor), I Povolzhskaja NauchnoPrakticheskaja Konferencija «Priborostroenie i Avtomatizirovannyj Jelektroprivod v Toplivnojenergeticheskom Komplekse i Zhilishhnokommunal'nom Hozjajstve», Kazan, 535-539 (2015) (in Russian)

24. V.P. D'jakonov, Spravochnik po algoritmam $i$ programmam na jazyke Bejsik dlja personal'nyh JeVM (Handbook on algorithms and programs in BASIC for personal computers, Moscow, Nauka, 240, 1987) (in Russian)

25. S. Manias, Power Electronics and Motor Drive Systems (2016)

26. B.J. Kwaha, E.A. Kolawole, A.M. Batu, Indian Journal of Science and Technology, 4, 451 (2011)

27. M. Atasoyu, B. Metin, H. Kuntman, O. Cicekoglu, International Journal of Electronics and Communications, 81, 205 (2017)

28. G. Moshic, P. Horn, Proektirovanie aktivnyh fil'trov (Engineering active filters, Moscow, Mir, 320, 1984) (in Russian). 